\title{
Pharmacology of some oral penicillins in the newborn infant
}

\author{
M. D. COHEN, J. A. RAEBURN, J. DEVINE, J. KIRKWOOD, B. ELLIOTT, \\ F. COCKBURN, and J. O. FORFAR \\ From the Departments of Child Life and Health and Therapeutics, University of Edinburgh, and Simpson \\ Memorial Maternity Pavilion, The Royal Infirmary, Edinburgh
}

\begin{abstract}
Cohen, M. D., Raeburn, J. A., Devine, J., Kirkwood, J., Elliott, B., Cockburn, F., and Forfar, J. O. (1975). Archives of Disease in Childhood, 50, 230. Pharmacology of some oral penicillins in the newborn infant. Serum and urine concentrations of ampicillin, amoxycillin, and flucloxacillin achieved after oral administration have been measured in 27 newborn infants. Compared with adults and children, newborn infants show a delay in achieving adequate blood concentrations, presumably due to delayed absorption. However most infants achieve therapeutic concentrations in the serum.

Infected newborn infants should be given these antibiotics by intramuscular injection for the first dose, but thereafter oral therapy $(25 \mathrm{mg} / \mathrm{kg}$ every 6 hours begun concomitantly) should be satisfactory. The better absorption of amoxycillin compared with ampicillin reported in adults has not been confirmed in the newborn infant.
\end{abstract}

The newborn infant differs from all other patients in his capacity to absorb, distribute, and excrete antibiotics. Compared with adults the time required to achieve peak serum levels after oral therapy is increased (Silverio and Poole, 1973). In addition, the excretion of most antibiotics is delayed (Axline, Yaffé, and Simon, 1967). Infants requiring antibiotics often have very little tissue into which intramuscular injections can be given and intravenous administration may be difficult or dangerous. We have studied the blood concentrations of ampicillin, amoxycillin, and flucloxacillin achieved by oral administration to neonates in a special care unit. During the study each infant remained on a normal feeding schedule and the antibiotics were given either singly or as the combined preparation of ampicillin and flucloxacillin (Magnapen).

\section{Materials and methods}

Twenty-seven infants were studied. 23 had indwelling catheters in the umbilical vessels (for the management of idiopathic respiratory distress syndrome, the administration of glucose to infants of diabetic mothers, or the performance of exchange blood trans-

Received 12 August 1974. fusion) and received antibiotic prophylactically after a full bacteriological screen had been performed. The 4 other infants received therapy for urinary tract infections. Table I summarizes details of the patients studied and the antibiotic prescribed; the majority of infants were preterm and most started antibiotic therapy in the first 48 hours of life.

All antibiotics were administered orally in syrup form. Those infants who could not swallow received treatment via a nasogastric tube. Otherwise the antibiotic was placed in the infant's mouth using a graduated syringe. The feeding schedule was not changed during therapy and at no time were the patients fasted. The first dose of antibiotic was given $2 \frac{1}{2}$ hours after a feed. No further antibiotic was given for 36 hours but thereafter a dose was given and repeated 6-hourly for 7 days.

Blood samples were collected by heel prick into one or more capillary tubes each containing $0.1 \mathrm{ml}$. After the first dose, samples were taken at the following times: $\frac{1}{2}, 1,2,4,6,9,12,15,18,24$, and 36 hours; at these times blood glucose or other biochemical tests were usually measured. Thereafter daily blood specimens were taken for antibiotic assay exactly 3 hours after the 6 a.m. dose. During the first 24 hours, four 6-hour urine collections were made; a 24-hour sample was collected between the 5 th and 6 th days. On the 7th day of therapy a stool sample was taken from each infant and from a control infant not receiving antibiotic. The antibiotic sensitivity of the predominant organism in 
TABLE I

Age, birthweight, gestation, and antibiotic therapy of the 27 infants (mean $\pm S D$ and ranges)

\begin{tabular}{|c|c|c|c|c|c|}
\hline Antibiotic & $\begin{array}{c}\text { Dose } \\
(\mathbf{m g} / \mathbf{k g})\end{array}$ & $\begin{array}{c}\text { No. of } \\
\text { patients }\end{array}$ & Age (d) & Birthweight (kg) & Gestation (w) \\
\hline $\begin{array}{l}\text { Ampicillin } \\
\text { Ampicillin/ } \\
\text { flucloxacillin } \\
\text { Flucloxacillin } \\
\text { Amoxycillin }\end{array}$ & $\begin{array}{l}25 \\
25 \\
25 \\
30\end{array}$ & $\begin{array}{l}9 \\
4 \\
7 \\
7 \\
7\end{array}$ & $\begin{array}{c}1 \cdot 4 \pm 1 \cdot 3 \\
(1-5) \\
1 \cdot 3 \pm 0 \cdot 5 \\
(1-2) \\
1 \cdot 6 \pm 1 \cdot 7 \\
(1-6) \\
1 \cdot 4 \pm 1 \cdot 1 \\
(1-4)\end{array}$ & $\begin{array}{c}2 \cdot 5 \pm 0 \cdot 8 \\
(1 \cdot 2-3 \cdot 8) \\
2 \cdot 7 \pm 1 \cdot 4 \\
(1 \cdot 8-4 \cdot 8) \\
2 \cdot 4 \pm 0 \cdot 5 \\
(1 \cdot 5-3 \cdot 0) \\
3 \cdot 0 \pm 0 \cdot 8 \\
(2 \cdot 2-4 \cdot 4)\end{array}$ & $\begin{array}{c}35 \cdot 3 \pm 3 \cdot 7 \\
(28-40) \\
35 \cdot 0 \pm 3 \cdot 5 \\
(32-40) \\
34 \cdot 7 \pm 4 \cdot 2 \\
(28-40) \\
37 \cdot 1 \pm 2 \cdot 1 \\
(34-40)\end{array}$ \\
\hline
\end{tabular}

these faecal samples was measured as previously described (Raeburn et al., 1973).

Antibiotic assay. After blood collection each sample tube was heat-sealed, care being taken to avoid heating of the blood by leaving $1 \mathrm{~cm}$ of air between the sealed end and the blood. When coagulation had occurred samples were spun in a microhaematocrit centrifuge for 15 minutes. About $0.05 \mathrm{ml}$ serum could be obtained from each tube for assay.

Assay plates were prepared by adding $0.5 \mathrm{ml}$ of an 18-hour culture of the test organism to each $100 \mathrm{ml}$ of molten medium maintained at $50^{\circ} \mathrm{C}$. This seeded medium (10 ml) was poured into disposable petri dishes (9 mm diameter). After cooling, $3 \mathrm{~mm}$ diameter holes were made in the agar layer using a suction punch. Table II gives details of the assay organisms and media for each of the antibiotics assayed and the most satisfactory range of antibiotic concentrations for standard solutions. For serum assays, standards were set up in pooled normal adult serum. Urine samples were diluted 1 in 10 with phosphate buffer and compared with standards prepared in the same buffer.

Test or standard solutions were pipetted into the wells in the agar plates so that each well was just full. 2 hours at room temperature were allowed for prediffusion and the plates were then incubated for 18 to 24 hours at $37^{\circ} \mathrm{C}$ depending on the density of growth. In general, with the Oxford Staphylococcus as test organism, 18 hours was sufficient to produce easily readable zones of inhibition; with Sarcina lutea 24 hours incubation was always required. The test diameters were compared with the appropriate standards and each concentration was determined using the mathematical method of Bennett et al. (1966). Whenever possible each sample was set up in quadruplicate and the mean used in calculating the test sample concentration.

Since small volumes of serum were taken from the infants who received ampicillin/flucloxacillin, only ampicillin concentrations have been measured using the assays at $p \mathrm{H} 7 \cdot 4$. Under these conditions flucloxacillin zones of inhibition were greatly exceeded by those due to ampicillin, therefore ampicillin alone was used in the standards. The urine samples from the patients who reciived this combination were assayed for both drugs.

\section{Results}

Table III shows for each antibiotic the mean serum concentrations at the various times after the first dose along with the ranges and standard deviations. Peak serum values of flucloxacillin were reached at 2 hours after oral administration, amoxycillin at between 4 and 9 hours, and ampicillin at 9 hours when given alone and 15 hours when given combined with flucloxacillin. Thus amoxycillin and ampicillin (alone or in the combination) appear to be slowly absorbed in these patients. Table IV shows the 3-hour serum levels for each successive day of therapy while on the 6-hourly administration regimen. No gross accumulation of antibiotic was

TABLE II

Antibiotic assay conditions

\begin{tabular}{|c|c|c|c|c|}
\hline Antibiotic & Test organism & Medium & $p \mathbf{H}$ & $\begin{array}{l}\text { Zones of inhibition } \\
\text { standard range }(\mathrm{mm})\end{array}$ \\
\hline Ampicillin & $\begin{array}{l}\text { (i) Oxford Staphylococcus } \\
\text { (ii) Sarcina lutea }\end{array}$ & $\begin{array}{l}\text { D.S.T.agar (Oxoid) } \\
\text { Antibiotic medium } \\
\text { No } 2 \text { (Oxoid) }\end{array}$ & $\begin{array}{l}7 \cdot 4 \\
7 \cdot 4\end{array}$ & $\begin{array}{r}25-0 \cdot 78 \\
1-0.06\end{array}$ \\
\hline Flucloxacillin & $\begin{array}{l}\text { Staphylococcus No. } 45 \\
\text { (B.R.L.) }\end{array}$ & $\begin{array}{l}\text { Antibiotic medium } \\
\text { No. } 2 \text { (Oxoid) }\end{array}$ & $6 \cdot 5$ & $25-1 \cdot 56$ \\
\hline Amoxycillin & Sarcina lutea & $\begin{array}{l}\text { Antibiotic medium } \\
\text { No. } 2 \text { (Oxoid) }\end{array}$ & $6 \cdot 5$ & $1-0.06$ \\
\hline
\end{tabular}


Mean serum concentrations $(\mu \mathrm{g} / \mathrm{ml})( \pm S D$ and range) after oral administration of ằing

\begin{tabular}{|c|c|c|c|c|c|c|}
\hline \multirow{2}{*}{ Antibiotic } & & & & & \multicolumn{2}{|r|}{ Antibiotic conc } \\
\hline & 0.5 & \multicolumn{2}{|c|}{1} & 2 & 4 & 6 \\
\hline $\begin{array}{l}\text { Ampicillin ( } 25 \mathrm{mg} / \mathrm{kg}) \\
\text { Ampicillin/flucloxacillin } \\
\text { ampicillin ( } 25 \mathrm{mg} / \mathrm{kg}) \\
\text { Flucloxacillin }(25 \mathrm{mg} / \mathrm{kg}) \\
\text { Amoxycillin }(30 \mathrm{mg} / \mathrm{kg})\end{array}$ & $\begin{array}{r}1 \cdot 1 \pm 2 \cdot 4 \\
(0-6 \cdot 5 \\
\\
0 \cdot 3 \pm 0 \cdot 3 \\
(0 \cdot 08-0 \cdot 7 \\
7 \cdot 0 \pm 11 \cdot \\
(0-21) \\
1 \cdot 1 \pm 1 \cdot 0 \\
(0-2 \cdot 8\end{array}$ & \multicolumn{2}{|c|}{$\begin{array}{c}0 \cdot 5 \pm 0 \cdot 3 \\
(0 \cdot 1-0 \cdot 7) \\
10 \cdot 2 \pm 14 \cdot 6 \\
(0-27 \cdot 5) \\
3 \cdot 3 \pm 2 \cdot 7 \\
(0-6 \cdot 6)\end{array}$} & $\begin{array}{c}2 \cdot 2 \pm 3 \cdot 3 \\
(0-9 \cdot 8) \\
\\
0 \cdot 6 \pm 0 \cdot 5 \\
(0 \cdot 1-1 \cdot 1) \\
15 \cdot 8 \pm 23 \cdot 1 \\
(0-42 \cdot 1) \\
3 \cdot 9 \pm 3 \cdot 1 \\
(2 \cdot 1-9 \cdot 0)\end{array}$ & $\begin{array}{c}1 \cdot 5 \pm 1 \cdot 5 \\
(0 \cdot 2-3 \cdot 7) \\
6 \cdot 8 \pm 5 \cdot 3 \\
(0-17 \cdot 4) \\
5 \cdot 1 \pm 3 \cdot 3 \\
(2 \cdot 4-10 \cdot 0)\end{array}$ & $\begin{array}{r}2 \cdot 6= \\
(0 \cdot 4= \\
2 \cdot 1 \\
(0 \cdot 1 \\
12 \cdot 0 \\
(0- \\
4 \cdot 1= \\
(2 \cdot 7\end{array}$ \\
\hline \multicolumn{5}{|c|}{$\begin{array}{r}\text { Mean serum antibiotic concentrations }(\mu g / m l)( \pm 1 S D \text { and range) taken } 3 \text { hours } \\
\text { receiving 6-hourly antibiotics for } 7 \text { days }\end{array}$} & \multicolumn{2}{|c|}{ after 6 a.m. dose in patient } \\
\hline \multirow{2}{*}{ Antibiotic } & \multicolumn{6}{|c|}{ 3-hour serum levels } \\
\hline & 2 & 3 & 4 & 5 & 6 & 7 \\
\hline $\begin{array}{l}\text { Ampicillin (25 mg/kg) } \\
\text { Ampicillin/flucloxacillin } \\
\text { ampicillin ( } 25 \mathrm{mg} / \mathrm{kg}) \\
\text { Flucloxacillin }(25 \mathrm{mg} / \mathrm{kg}) \\
\text { Amoxycillin }(30 \mathrm{mg} / \mathrm{kg})\end{array}$ & $\begin{array}{l}9 \cdot 7 \pm 4 \cdot 1 \\
(5 \cdot 0-16 \cdot 3) \\
\\
7 \cdot 9 \pm 8 \cdot 4 \\
(2 \cdot 0-17 \cdot 5) \\
20 \cdot 8 \pm 13 \cdot 5 \\
(5 \cdot 7-28 \cdot 0) \\
10 \cdot 9 \pm 7 \cdot 1 \\
(3 \cdot 2-19 \cdot 5)\end{array}$ & $\begin{array}{l}12 \cdot 8 \pm 6 \cdot 2 \\
(7 \cdot 2-23 \cdot 1) \\
\\
12 \cdot 2 \pm 13 \cdot 5 \\
(1 \cdot 3-27 \cdot 3) \\
15 \cdot 3 \pm 7 \cdot 8 \\
(4 \cdot 1-23 \cdot 1) \\
8 \cdot 9 \pm 5 \cdot 9 \\
(3 \cdot 6-15 \cdot 0)\end{array}$ & $\begin{array}{c}10 \cdot 5 \pm 6 \cdot 5 \\
(3 \cdot 0-17 \cdot 9) \\
\\
15 \cdot 5 \pm 16 \cdot 5 \\
(0 \cdot 6-34 \cdot 4) \\
7 \cdot 2 \pm 4 \cdot 1 \\
(3 \cdot 6-10 \cdot 5) \\
7 \cdot 7 \pm 4 \cdot 6 \\
(4 \cdot 3-14 \cdot 8)\end{array}$ & $\begin{array}{c}9 \cdot 5 \pm 8 \cdot 7 \\
(2 \cdot 2-24 \cdot 4) \\
\\
12 \cdot 4 \pm 15 \cdot 8 \\
(2 \cdot 6-30 \cdot 6) \\
18 \cdot 6 \pm 7 \cdot 7 \\
(10 \cdot 3-25 \cdot 6) \\
8 \cdot 3 \pm 4 \cdot 8 \\
(5 \cdot 3-13 \cdot 5)\end{array}$ & $\begin{array}{l}10 \cdot 6 \pm 5 \cdot 5 \\
(4 \cdot 2-18 \cdot 0) \\
\\
12 \cdot 3 \pm 14 \cdot 6 \\
(3 \cdot 7-29 \cdot 6) \\
19 \cdot 2 \pm 9 \cdot 2 \\
(12 \cdot 8-25 \cdot 6) \\
8 \cdot 4 \pm 4 \cdot 0 \\
(3 \cdot 7-14 \cdot 0)\end{array}$ & $\begin{array}{c}11 \cdot 7 \pm 5 \cdot 8 \\
(5 \cdot 7-21 \cdot 6) \\
4 \cdot 9 \pm 3 \cdot 4 \\
(2 \cdot 6-7 \cdot 3) \\
22 \cdot 3 \pm 11 \cdot 8 \\
(0-37 \cdot 2) \\
9 \cdot 4 \pm 5 \cdot 4 \\
(7 \cdot 2-14 \cdot 8)\end{array}$ \\
\hline
\end{tabular}

observed. Throughout the period of therapy there was considerable variation in the serum concentrations achieved between different patients.

The mean urinary concentrations of each antibiotic in the 6-hour collections made on the first day are shown in Table V. For all antibiotics,

TABLE V

Mean urinary concentrations $(\mu \mathrm{g})$ during 1 st 24 hours

\begin{tabular}{l|c|c|c|c}
\hline \multirow{2}{*}{ Antibiotic } & \multicolumn{3}{|c|}{6 -hour collections } \\
\cline { 2 - 5 } & $0-6$ & $6-12$ & $12-18$ & $18-24$ \\
\hline Ampicillin & 196 & 449 & 202 & 141 \\
Ampicillin/ & & & & \\
$\quad$ flucloxacillin & & & \\
$\quad$ (i) Ampicillin & & & \\
(ii) Flucloxacillin & 173 & 122 & 31 & - \\
Flucloxacillin & 133 & 116 & 48 & - \\
Amoxycillin & 120 & 100 & 124 & 122 \\
& 92 & 102 & 469 & 224 \\
\hline
\end{tabular}

less than $30 \%$ of the administered dose was excreted in the urine during the first 24 hours, but comparison between the drugs is not possible because of the wide variation of individual results and the difficulties in ensuring complete collection of all the urine excreted.

Four infants with Esch. coli urinary tract infections proven by suprapubic aspiration and treated with amoxycillin ( $120 \mathrm{mg} / \mathrm{kg}$ per 24 hours) for 14 days had sterile urine cultures at the end of treatment. All remained free from recurrence for more than 2 years. In infants given ampicillin or ampicillin/ flucloxacillin the predominating stool organism was resistant to ampicillin in $75 \%$ of cases and to cloxacillin in $75 \%$ of cases after 7 days' treatment. At this time the infants given flucloxacillin had predominating stool organisms resistant to ampicillin in $75 \%$ of cases and to cloxacillin in $100 \%$ of cases. In the control babies not treated with any antibiotic the predominating stool organism was resistant to ampicillin in $40 \%$ of cases and to cloxacillin in $93 \%$ of cases.

\section{Discussion}

In most but not all newborn infants serum concentrations within the therapeutic range can be achieved when ampicillin, amoxycillin, and 
เ after oral dose)

\begin{tabular}{|c|c|c|c|c|c|}
\hline 9 & 12 & 15 & 18 & 24 & 36 \\
\hline $\begin{array}{c}6 \cdot 9 \pm 10 \cdot 9 \\
(2 \cdot 6 \pm 33 \cdot 6)\end{array}$ & $\begin{array}{l}3 \cdot 6 \pm 4 \cdot 5 \\
\quad(0-14 \cdot 8)\end{array}$ & $\begin{array}{c}1 \cdot 8 \pm 0 \cdot 4 \\
(1 \cdot 5-2 \cdot 1)\end{array}$ & $\begin{array}{r}1 \cdot 6 \pm 1 \cdot 4 \\
(0-3 \cdot 4)\end{array}$ & $\begin{array}{r}1 \cdot 2 \pm 1 \cdot 7 \\
(0-4 \cdot 1)\end{array}$ & $\begin{array}{c}0.7 \pm 0.9 \\
(0.1-1 \cdot 5)\end{array}$ \\
\hline $\begin{array}{c}4 \cdot 5 \pm 2 \cdot 5 \\
(1 \cdot 0-6 \cdot 7) \\
2 \cdot 1 \pm 4 \cdot 4 \\
(0-6 \cdot 2) \\
5 \cdot 2 \pm 3 \cdot 0 \\
(2 \cdot 2-8 \cdot 6)\end{array}$ & $\begin{array}{c}3 \cdot 9 \pm 3 \cdot 9 \\
(0 \cdot 9-8 \cdot 4) \\
2 \cdot 1 \pm 4 \cdot 5 \\
(0-6 \cdot 3 \\
3 \cdot 6 \pm 2 \cdot 2 \\
(1 \cdot 7-6 \cdot 8)\end{array}$ & $\begin{array}{c}5 \cdot 2 \pm 5 \cdot 6 \\
(0 \cdot 9-11 \cdot 6) \\
1 \cdot 8 \pm 3 \cdot 6 \\
(0-3 \cdot 6) \\
4 \cdot 7 \pm 4 \cdot 6 \\
(0 \cdot 7-12 \cdot 1)\end{array}$ & $\begin{array}{c}1 \cdot 3 \pm 1 \cdot 5 \\
(0 \cdot 1-3 \cdot 0) \\
0 \\
4 \cdot 4 \pm 3 \cdot 3 \\
(0 \cdot 9-8 \cdot 0)\end{array}$ & $\begin{array}{c}2 \cdot 3 \pm 1 \cdot 3 \\
(0 \cdot 3-3 \cdot 9) \\
0 \\
4 \cdot 1 \pm 3 \cdot 2 \\
(0 \cdot 8-8 \cdot 0)\end{array}$ & $\begin{array}{c}0.3 \pm 0.3 \\
(0 \cdot 1-0 \cdot 8) \\
0 \\
2 \cdot 2 \pm 0.9 \\
(1 \cdot 4-3 \cdot 1)\end{array}$ \\
\hline
\end{tabular}

flucloxacillin are given orally; peak levels are only achieved after some hours delay. This is presumably due to slow absorption in the immature infant gut. We have noted similar delayed absorption with cephalexin (Cockburn, Raeburn, and MacMillan, 1972) and fusidic acid (unpublished data). A practical application of this finding is that the first dose of these antibiotics should be given parenterally: thereafter oral treatment started at the same time is usually satisfactory. In marked contrast to the situation in healthy adults (Sutherland, Croydon and Rolinson, 1972), amoxycillin has no advantage over ampicillin in respect of absorption in infants. However, our patients were a special group who had pre-existing severe diseases. This is emphasized by the lower serum levels of ampicillin in this study compared with the results of Grossman and Ticknor (1965). After oral administration of ampicillin $(20 \mathrm{mg} / \mathrm{kg}$ in one single dose) to term normal neonates these authors noted a mean peak serum level of $32.4 \mu \mathrm{g} / \mathrm{ml}$ at 4 hours. Silverio and Poole (1973) showed that after an oral dose of $10 \mathrm{mg} / \mathrm{kg}$ ampicillin mean peak serum levels of $4 \mu \mathrm{g} / \mathrm{ml}$ could be attained, i.e. levels achieved in our study after a higher dose. Flucloxacillin appears to be better absorbed in our sick babies, but the levels still fall well below the cloxacillin levels reported after oral administration to healthy neonates (Grossman and Ticknor, 1965). In neonatal patients good antibiotic management demands that assays be performed to ensure that adequate serum concentrations are achieved.

The percentages of the doses of each penicillin excreted in the urine are lower than those reported in adults (Kosmidis et al., 1972) and are in keeping with the results reported by Axline and co-workers (1967) after intramuscular injections in the neonatal period. During the first week of life the renal clearance of antibiotic increases quite rapidly.
Thus, though the delay in excretion noted during the first 36 hours would if persistent lead to cumulation, this did not occur even on the 6-hourly dose regimen. The levels noted during the 6 days of regular treatment suggest that the serum half-lives of all antibiotics were less than 2 hours. During the first 2 days of treatment, therefore, the pharmacodynamic situation is very unusual.

Urinary concentrations of the penicillins, even during the first day, were within the therapeutic range and this suggests that these agents are suitable for the treatment of urinary infections. Thus amoxycillin was rapidly effective in the treatment of 4 such infants.

When ampicillin/flucloxacillin is given, it appears that there is a delay before therapeutic concentrations of ampicillin are achieved in the serum when compared with infants who receive ampicillin alone. However, the urine studies suggest that slightly lower concentrations occur after the combination. Furthermore there may be more variation in the daily ampicillin concentrations when the combination is given. All these points are of relevance whenever combined antibiotic therapy is given and may indicate competition between the two penicillins for absorption, distribution, and excretion. We know of no studies which clarify this situation either in the neonate or in adults.

\section{REFERENCES}

Axline, S. G., Yaffé, S. J., and Simon, H. J. (1967). Clinical pharmacology of antimicrobials in premature infants. Pediatrics, 39, 97.

Bennett, J. V., Brodie, J. L., Benner, E. J., and Kirby, W. M. M. (1966). Simplified accurate method for antibiotic assay of clinical specimens. Applied Microbiology, 14, 170.

Cockburn, F., Raeburn, J. A., and MacMillan, M. (1972). Cephalexin and the newborn human infant. Advances in Antimicrobial and Antineoplastic Chemotherapy. Ed. by M. Hejzlar, M. Semonsky, and S. Masak. Urban and Schwarzenberg, München. 
Grossman, M., and Ticknor, W. (1965). Serum levels of ampicillin, cephalothin, cloxacillin and nafcillin in the newborn infant. Antimicrobial Agents and Chemotherapy, p. 214. Ed. by G. L. Hobby. American Society for Microbiology, Ann Arbor, Michigan.

Kosmidis, J., Williams, J. D., Andrews, J., Goodall, J. A. D., and Geddes, A. M. (1972). Amoxycillin-pharmacology, bacteriology and clinical studies. British fournal of Clinical Practice, 26, 341.

Raeburn, J. A., Sinclair, R. D. C., Nimmo, J., Price, J. D., and Henderson, J. T. (1973). Broad or narrow spectrum therapy ? studies with ampicillin and azidocillin in acute chest infections. Scandinavian Fournal of Infectious Diseases, 5, 141
Silverio, J., and Poole, J. W. (1973). Serum concentrations of ampicillin in newborn infants after oral administration. Pediatrics, 51, 578.

Sutherland, R., Croydon, E. A. P., and Rolinson, G. N. (1972). Amoxycillin: a new semi-synthetic penicillin. British Medical fournal, 3, 13.

Correspondence to Dr. F. Cockburn, Paediatric Department, Simpson Memorial Maternity Pavilion, Lauriston Place, Edinburgh EH3 9EF. 